\title{
Precisamos falar sobre o jomalismo como forma de conhecimento
}

\section{Gabriela ALMEIDA ${ }^{1}$}

No livro O segredo da pirâmide - Para uma Teoria marxista do jornalismo, publicado em 1987 e com autoria de Adelmo Genro Filho, encontram-se questionamentos que abalam até hoje o fazer do jornalista. Para quem a Teoria do jornalismo está sendo criada? Para a academia? Para uma minoria de jornalistas que têm em seu nome uma marca registrada? Para os donos de empresas jornalísticas? O professor e pesquisador da Universidade Estadual de Ponta Grossa, Felipe Simão Pontes, ao publicar o livro Adelmo Genro Filho e a Teoria do Jornalismo (2015) não só reavive essas questões como também se preocupa em detalhar as repostas dadas por Genro Filho e em tentar solucionar as lacunas deixadas pelo autor.

Resultado da sua tese de doutoramento defendida na Universidade Federal de Santa Catarina, em 2015, o livro de Pontes é dividido em duas partes, a saber: Adelmo Genro Filho e a Teoria do Jornalismo no Brasil (Capítulos 1, 2 e 3) e Uma análise crítica (4 e 5). A partir dessa divisão é perceptível uma preocupação primária em Pontes: para entender a fundo a proposta de Genro Filho em seu livro não basta determinar o seu lugar de fala no tempo, nesse caso o Brasil da década de 1980. É também de suma importância entender quem foi o sujeito Adelmo Genro Filho e suas relações intelectuais.

O capítulo $O$ jornalismo brasileiro e as mediações de uma teoria, abertura da primeira parte do livro, faz uma panorâmica da conjuntura sócio-política-histórica do jornalismo daquele tempo. Para tanto, Pontes utiliza quatro artigos publicados na Folha de São Paulo como ferramenta ilustrativa do desentendimento entre aqueles que eram avessos à obrigatoriedade do diploma - dispensando uma abordagem teórica e formação 
especializada para o jornalismo, o identificando como uma técnica - e os teóricos do jornalismo - que não faziam um esforço significativo para a abertura de um diálogo entre teoria e prática. Publicados no dia 5 de agosto de 1984, três anos antes da publicação do Segredo da pirâmide, os quatro textos saíram no caderno "Folhetim" e desenham bem o momento por qual passava o jornalismo. O primeiro texto, um manifesto político do então diretor de redação da época, Otávio Frias Filho, defendia características da notícia similares às do jornalismo estadunidense; o segundo texto, do acadêmico Carlos Eduardo Lins da Silva, segurava o jargão de que "a teoria na prática é outra"; o terceiro, do jornalista da casa, Matinas Suzuki Jr, alimentava o ódio dos intelectuais pelos jornalistas; e, por fim, o texto de Caio Túlio Costa, Secretário de redação da Folha, tratava do ódio de forma inversa, dos jornalistas para os intelectuais.

Para além das desavenças dos jornalistas com seus pares e com os intelectuais, Pontes indica algumas mudanças ocorridas no cenário do jornalismo. Com a abertura política e o retorno das liberdades no início da década de 1980, jornalistas da esquerda migravam das publicações alternativas e de combate ao regime civil-militar, que começavam a minguar, para as redações dos tradicionais jornais do País. A ampliação de Assessorias de Comunicação e imprensa expandiu o mercado para os jornalistas; por outro lado, foi notório o aumento das escolas de Comunicação Social, que proporcionaram um maior número de mão de obra disponível. E são para esses jornalistas recém-formados, que vão constituir a classe proletária do jornalismo, para quem Adelmo Genro Filho escrevia e, consequentemente, para quem também se retrata Felipe Pontes.

Após localizar no tempo e no espaço a obra de Genro Filho e montar um paralelo entre $O$ segredo da pirâmide, a história do jornalismo e as mediações presentes na profissão e na academia nos anos de 1980, Pontes dedica seu segundo capítulo, intitulado Singularidade de uma vida em suas mediações históricas, à vida do autor. Ele assim o faz por perceber ser importante entender a história do sujeito Genro Filho para explicar a sua teoria do jornalismo. A partir de entrevistas com pessoas próximas a Genro Filho, Pontes faz uma análise histórico-social do sujeito-autor em seu contexto cultural, social e político para entender possíveis influências geográficas, familiares e de posicionamentos políticos, por exemplo, na trajetória do intelectual. O esforço de Pontes ultrapassa o simples relato da vida do outro. As oitenta e sete páginas que compõe o 
segundo capítulo de seu livro dariam por si só outro livro: a biografia de Adelmo Genro Filho.

Filho de Adelmo Simas Genro e Elly Herz Genro, Genro Filho tem sua vida marcada pela militância, pela política e pelo meio intelectual. Seu pai foi vereador por duas vezes e vice-prefeito de Santa Maria, no interior do Rio Grande do Sul, e também foi professor de português e francês e diretor no Ginásio Estadual de São Borja (RS), cidade em que Genro Filho nasceu em 1951. A sua mãe é descrita como uma leitora assídua e militante ativa em partidos como MDB, PMDB e PT. Mas, segundo Pontes, não só a formação oferecida pelos pais foi responsável pelo desenvolvimento intelectual de Genro Filho. Para a construção da sua biografia, também é levado em consideração "a cidade de Santa Maria como polo estudantil, ferroviário e militar, o reconhecimento local como integrante de uma família de esquerda, o contexto político do Brasil" (PONTES, 2015, p. 109). Pontes vai a fundo para captar o ambiente em que Genro Filho cresceu e desenvolveu sua intelectualidade, chegando a descrever detalhes da organização da casa onde os Genros moraram na cidade de Santa Maria.

Genro Filho formou-se em Comunicação Social/ Jornalismo em 1975 pela Universidade Federal de Santa Maria; foi eleito vereador pelo MDB de Santa Maria no ano de 1976; em 1982 ingressa, por concurso público, como professor do curso de jornalismo da Universidade Federal de Santa Catarina. Adelmo Genro Filho morreu em 1988, um ano após o lançamento do seu livro.

No terceiro e último capítulo da primeira parte, Os caminhos da teoria e suas conexões com a profissão, o ensino e a pesquisa em jornalismo, Pontes elabora minuciosa pesquisa para cria uma "topografia" dos estudiosos que citam e usam a teoria proposta por Genro Filho. Esse desenho geográfico da teoria do jornalismo como forma de conhecimento não só é importante para uma análise de como essa teoria proposta por Adelmo é entendida por outras pesquisas, mais principalmente para mapear alguns conflitos que se concretizam no cenário da pesquisa em jornalismo no Brasil. Conflito marcado principalmente entre as escolas de Comunicação Social do eixo Rio-São Paulo e as escolas de Jornalismo do Sul do país.

A segunda parte do livro, Uma análise crítica, é composta pelos capítulos 4 e 5 e resultado direto da análise da dissertação de Genro Filho defendida na UFSC um ano antes de ser publicada em livro. Apesar de ser a menor parte da obra, esse momento é o mais denso. Feita a construção do tempo em que Genro Filho falava, o desenho de como 
suas ideias trafegaram nas pesquisas acadêmicas do país, a investigação e análise do sujeito Genro Filho e seu desenvolvimento intelectual, Pontes começa, em Fundamento Ontológicos de uma teoria de jornalismo, a alinhavar os capítulos anteriores por uma linha lógica para nos apresentar a ontologia e a epistemologia que defendia Genro Filho, elementos chaves para o entendimento do Segredo da pirâmide. Segundo Pontes, o obstáculo para essa compreensão "está no uso de conceitos esparsos do livro em ambiências conceituais estranhas às proposições do autor" (PONTES, 2015, p. 256). Para entender o "segredo" de Genro Filho é necessário conhecer o contexto de produção da sua teoria marxista do jornalismo, o que justifica o caminho escolhido por Pontes em seu livro. Ambientando o seu leitor à biografia e ao ponto de vista do mundo de Genro Filho. Desta forma, Pontes passa a apresentar como Genro Filho conceituou a realidade, a objetividade e a subjetividade, o jornalismo e a ideologia (e a relação entre eles), além de detalhar o entendimento do autor sobre a necessidade social da notícia e os critérios de noticiabilidade.

No quinto e último capítulo, intitulado O jornalismo como forma de conhecimento, Pontes dá o ultimo ponto em sua costura lógica de ideias ao explicar detalhadamente os conceitos centrais para a compreensão do jornalismo como forma de conhecimento a partir da visão de Genro Filho: as categorias de singularidade, particularidade e universalidade. Para além disso, Pontes também faz uma revisão do conceito de conhecimento. Vale ressaltar que neste momento do livro Pontes realiza uma análise crítica e, por essa razão, estabelece um diálogo aberto com os elementos construídos por Adelmo para uma teoria marxista do jornalismo, nos deixando com a nítida sensação de um continuo esforço de aperfeiçoamento do passado.

Em um cenário que se fala constantemente nas crises do jornalismo, o livro Adelmo Genro Filho e a teoria do jornalismo, de Felipe Pontes, ao relançar questões cruciais para o fortalecimento e a boa prática do jornalismo, reestabelece a necessidade de se falar do jornalismo como forma de conhecimento e o faz com maestria. Um livro denso, cheio de detalhes, revisões e o esforço de estabelecer conceitos e a delicadeza de quem admira e respeita o trabalho do outro.

Recebido em 26/10/2016

Publicado em 20/11/2016

Revista Pauta Geral-Estudlos em J omalismo, Ponta Grossa, vol.3, n. 2, p.163-166 , J ul/Dez 2016. 